\title{
Modes of Marginality: Scottish Literature and the Uses of Postcolonial Theory ${ }^{1}$
}

\section{LIAM CONNELL}

Although not widely regarded as an example of a postcolonial literature, several attempts have been made to apply the theoretical perspectives generated by postcolonialism to Scottish literature as a national body of writing. This has largely taken two forms. In the first instance there have been several explicit attempts to use a postcolonial terminology to explain the prevalent formal characteristics of Scottish literature and to offer new perspectives on Scottish literature's relation to the mainstream of literature in English. ${ }^{2}$ There has also been a second and substantially more prominent strand of critical engagement with postcolonial theory that might be described as a catchphrase criticism, which has seen critics loosely apply the terminology of postcolonialism without any extended explanation of its suitability and without a sustained application of the theoretical methodologies from which these terms derive. Despite its strengths, Robert Crawford's Devolving English Literature is indicative of this last approach. Although he applauds Edward Said's Orientalism for offering a suggestive methodology for examining "cultural difference,"3 his work continues to treat Scottish literature as a coherent and a priori entity with no sensitivity to the fact that it might also constitute "a system of representations framed by a whole set of forces" that excludes the possibility of such difference. ${ }^{4}$

While the former strand of criticism often displays a careful effort to assess the utility of postcolonial theory for Scottish literary studies, both approaches appear to share certain motivations and assumptions about Scottish literature and about the nature of postcolonial theory, which illuminate the political limitations of postcolonialism's endless translation into new and unforeseen contexts. In order to demonstrate this, this article will argue that the use of postcolonial theory in relation to Scottish literature forms a strategic effort to raise the profile of Scottish literary studies within the context of its institutional marginalization as an area of study within British and North American universities. It will be suggested that, because the growth of postcolonialism within English studies has outstripped the study of Scottish literature, critics working on Scottish litera- ture have increasingly sought to link their work to postcolonialism in order to persuade a wider academic community that their research is relevant to the main concerns of the discipline. However, while English literature's homonymic conflation of writing in English and writing by the English allows it to be defined in cosmopolitan terms, Scottish literature is denied the same eclectic absorption of international writers because its coherence is defined by a political concept of Scottishness: because "Scottish" is not a language, Scottish literature is always literature from Scotland. As a result, the inclusion of postcolonial subject matter in the study of Scottish literature requires a rationale beyond its inclusion in the syllabus of English studies. Because they often write in English, so-called postcolonial writers can be studied within an "English literature" degree program without significantly impinging upon the ways of reading other English-language writers even if the hope is always that this will lead to a general reassessment of all writing. By contrast, the inclusion of postcolonialism in the study of Scottish literature must either perform some form of Saidian discourse analysis of the racial politics of Scottish texts or indicate the extent to which Scottish authors are postcolonial by demonstrating a degree of cultural marginalization within Anglocentric British political structures. Ironically, in order to position Scottish literature closer to the center of critical work in English studies at the institutional level, critics have been required to constitute Scottish literature as something on the margins of this work at the political level. The neglect of Scottish literature as a subject area is therefore explained by reference to a social marginalization in common with authors from the former British colonies.

This conflation of critical and social marginalization may result from postcolonialism's central concern to account for a cultural component in the systems of domination that resulted from colonization. Although the attention of postcolonial cultural explanations is frequently to literary techniques, their basis is fundamentally political and requires the use of political terminology. This shift from the textual to the political is ap- 
parent in many of the attempts to account for stylistic similarities between Scottish and so-called postcolonial texts, whereby critics offer material, rather than literary explanations, for this resemblance. Most commonly, the adoption of postcolonial theory to analyze Scottish texts sees critics explain Scottish literature's formal properties in terms of a history of English colonization of Scotland (often flagged as a precursor to British imperialism). The designation of Scotland as an English colony is highly controversial and displays a dazzling confusion of textual and social forms of exclusion. This essay attempts to explain why this formula has become so prevalent in recent years and suggests three main causes: first, changes to the Scottish economy and to British political structures, which made such an explanation more palatable to Scots than it was earlier in the twentieth century; second, developments in the economy of the university as an institution which prioritized academic publication and made the marketability of research a more pressing concern; and finally, a structural nationalism in the concept of Scottish literature that conceives the relationship between Scottish and English culture in antagonistic terms, and which identifies liberationist nationalism as quintessentially postcolonial. This sense of postcolonialism derives from a terminological confusion over the meaning of its political vocabulary, chiefly in blurring the concepts of colonization, which constitutes the variegated practices of economic extraction and territorial settlement by one state over another, and imperialism, which constitutes a global system of development in which capital is increasingly internationalized. Although colonization was a significant means of advancing imperialism it was not the only means. The danger of confusing these two terms is that it tends to depict all forms of social exclusion as equivalent and obscure the continuing significance of imperialism in constructing economic inequalities at the international level.

In describing the conceptual developments in Scottish studies this essay relies heavily on a political and economic analysis rather than literary criticism. This is due in no small part to the working assumption that literary meaning is mediated by certain formal institutions, particularly in the context of academic analysis. Therefore, in order to understand how a term like the postcolonial comes to be meaningful, it is insufficient to address the nature of the writing that this term purports to include. Rather it is necessary to look at the mechanisms through which this term is given meaning; mechanisms that constantly need to negotiate the material conditions in which literary production takes place. In recent years critics of modernist writing have begun to examine a range of institutions that facilitated the canonization of Modernism. ${ }^{5}$ A similar analysis of the institutional and economic contexts that have allowed the proliferation of postcolonial studies needs to be conducted by postcolonial critics. This is particularly pressing in light of the way that the increasing textualization of postcolonialism's analysis can be seen to have domesticated many of the terms of its critique. The reliance upon social and political analyses in this essay is partly intended to assess what is gained from deploying postcolonialism as an analytic framework, both in relation to Scotland and in general. There is always the danger that postcolonialism simply exoticizes writing from other cultures and seals off the curricular space where African, Asian and Caribbean writers can be discussed. ${ }^{6}$ Yet, what differentiated postcolonialism from previous categories such as Commonwealth literature was its politicization of writing as it spoke to the power relations between metropolitan and non-metropolitan political and economic spaces. Regardless of its attention to the literary, Said's Orientalism was concerned to trace how textuality facilitated the "West's" continuing dominance of the "East" in social and political terms. How ever, because of the disciplinary specialization that informs the structure of most academic institutions, the juxtaposition of political and textual explanations presents difficulties for a teacher wishing to introduce students to postcolonialism. In literary studies, the desire to introduce postcolonialism into a general literary degree program often requires that the sociopolitical questions underpinning a postcolonial analysis become secondary to its curricular function in facilitating the study of certain types of texts. This may be particularly true as postcolonialism is extended to an increasing number of contexts, the consequence of which is a need to rely upon theoretical models that lack a materialist specificity in favor of a general applicability. Nevertheless, even if unspoken, political concerns remain the subtext of the use of postcolonial methodologies for textual analysis. As such, it becomes necessary to ask how appropriate the language of colonialism is for any particular historical context. Answering this question, necessarily, requires the sort of social and political analysis that will be offered here. Yet the intent in doing so is not to deflect attention from literary characteristics so much as to indicate how a particular manifestation of such characteristics relies upon certain ways of understanding the political and economic conditions governing literary relations.

\section{Was Scotland Colonized?}

Bearing in mind such concerns, it is appropriate to note that although postcolonial theory is often seen as applicable to contexts that are not colonial, or at least not obviously so, the assertion that Scotland was colonized by England has been an important component in the application of postcolonialism to Scottish literary studies. While controversial this claim appears to have a 
gained a certain popular currency in contemporary discussions of Scotland, with commentary in major national newspapers describing Scotland as "England's Last Colony" and the Scots as a colonized people.7 Academic studies have mirrored such bold assertions of Scotland's status as an English colony. For instance, in a 1997 account of teaching "Scottish and Postcolonial Studies" as part of the degree in English literature at Stirling University, Douglas Mack celebrated the "intellectual excitement" his students felt "as a picture began to emerge of Scotland as a society which has been both coloniser and colonised." 8 This claim is supported by literary rather than political comparisons with Mack reading textual characteristics as the transparent representation of social formations. As such it exhibits all of postcolonialism's problematic slippage between the textual and the political. In a more recent example, exploring the "Celtic connections" between Scotland and Ireland, Ellen-Raïssa Jackson and Willy Maley identified "colonialism" as the source of "historical and political" parallels between these countries and claimed, "Scottish and Irish critics have long recognized the degree to which, in a British context, colonialism begins at home." Typically, Jackson and Maley offer nothing to substantiate this claim at the material level, seemingly viewing colonization as primarily a cultural phenomenon. Moreover, this assertion is somewhat superfluous to the content of their essay, which involves an interesting comparison of Scottish and Irish linguistic experimentation. ${ }^{10}$

This type of explicit statement about Scotland's colonization is present even in work that displays a theoretically nuanced use of postcolonial writing. For example, an essay by Berthold Schoene uses Homi Bhabha's notion of a "third space" to challenge the concept of a coherent Scottishness, attributing the adoption of the symbols of Highland Scotland by Anglicized Lowland Scots to their need for a Scottish cultural-particularity as a component of modern nationalism. Yet, for all its subtlety, Schoene's attempt to offer a cause for these events reverts to the sort of unsubstantiated descriptions of English imperialism already described. Schoene argues that events like the Highland Clearances (the forcible dispossession of feudal tenants from Highland lands) were "instigated by England, eager to expand its sphere of influence even to the most remote regions of the British Isles," and interprets this as part of a "colonial enterprise," which "operated at the command of the English imperial centre." 11 In the absence of any explanation of how this "command" was exercised, England's dominance over Scotland is assumed absolutely yet remains curiously disconnected from other important contemporaneous developments within the British state, such as the end of Absolutism and the development of a more identifiably modern political appa- ratus. ${ }^{12}$

In other critical work the use of a colonial model for Scottish history is employed more obliquely. For example, in his wide-ranging book on Scottish culture, Cairns Craig, employs Frantz Fanon's description of psychic disruption in Black Skin, White Masks to help understand Scottish identity in a culture that purportedly overvalues English versions of Britishness. Although not explicitly claiming that Scotland was a colony, Craig assumes that the cultural response to its political settlement is the same. He goes further:

If the Scots were indeed, as is often claimed, the backbone of the Empire, it is perhaps because only before the eyes of the backward could they play with success, the role of fully achieved civilised Britishness to which they aspired.

It is not by our colour that we have stood to be recognised as incomplete within the British context, it is by the colour of our vowels: the rigidity of class speech in Britain, the development of Received Pronunciation as a means of class identity, is the direct response of a dominant cultural group faced by a society in which the outsiders are indistinguishable by colour. ${ }^{13}$

By aligning his colonial imagery with the politics of "class speech in Britain," Craig disguises the degree to which his analysis racializes Scots as the Other to Britain's "dominant cultural group." The apparent desire to absolve Scots from their participation in Empire leads Craig to depict their role as the product of their marginalization at home. To that end, he appears to repeat Jackson and Maley's claim that England's colonization of Scotland was a necessary precursor to Britain's outward colonial expansion. Yet such claims could similarly be made for English working-class participants in the British Empire, and Craig's singling out of Scots leads him into a racial metaphor that constitutes nonstandard Scottish speech patterns as equivalent to the chromatic differences central to colonial racial typographies. While the physical attributes used for racial categories are partially the constructs of racially-normative political hierarchies, skin tone remains an organic attribute that forms a poor counterpart to the socially constituted and highly mutable properties of speech. By equating, apparently unproblematically, Scots' linguistic incompleteness in a British context with the racial "backwardness" of colonized populations, Craig implicitly identifies Scottishness as an organic marginality that debars them from constituting Britain's ruling elite.

Fairly typical of the use of postcolonial theory in relation to Scottish literature, these accounts appear to demonstrate a need to claim political domination in order to explain the nature of Scottish writing. ${ }^{14}$ Certainly, the issues they address are not simply literary ones and their use of the language of colonization seems intent 
on proving that Scots have been historically unable to play "the role of fully achieved civilised Britishness" because of the marginalization of Scotland by an English-centered British elite. Yet, tellingly, the writing that this narrative seeks to elucidate is often highly canonical within a tradition of English literature. In order to reconcile this canonicity with the colonial narrative of Scotland's political domination and to constitute Scottish literature as a coherent area of study, it become necessary to rewrite the canonical status of individual Scottish authors as a form of misrecognition, whereby they are mistaken as "English" due to the incorporating tendencies of a dominant English culture intent on claiming for itself a monopoly on cultivation. Like Scots' participation in the British Empire, Scottish texts such as James Thomson's "Rule Britannia" can be identified as the product of Scots' desire to appear "civilised" in the face of cultural-hierarchies that refuse to recognize Scottishness as capable of civilization. ${ }^{15}$ Postcolonialism may help to explain the appropriation of Scottish texts as "English," and a theory such as Bhabha's notion of mimicry might go some way to describing this process. ${ }^{16}$ However, despite Bhabha's deeply postmodern theoretical orientation, his concept of mimicry depends upon an underlying assumption about the political inequalities of the two cultural systems at play within it: assuming a group of politically disenfranchised practitioners of the dominant cultural forms. In order to reclaim texts by Scots from English literature and to situate them in a wholly Scottish tradition, it is therefore necessary to locate the canonization of Scottish authors within a system of inequality whereby Scottishness is subordinate to Englishness as an ideal of normative Britishness. From this starting point a great deal of recent criticism on Scottish literature has concentrated upon the disruptive consequences of the, apparently, enforced adoption of English models of civilized culture in Scotland at the expense of native cultural formations. ${ }^{17}$

Emblematically, the focus of these accounts has been on the use of language, with the adoption of Standard English leading to the suppression of Scottish language varieties such as Gaelic or Scots. ${ }^{18}$ However, linguistic standardization in and of itself is not an indication of colonization and cannot justify the claims that Scotland was colonized. A comparable analysis would be the suggestion that England had been colonized by itself because large portions of the English population speak nonstandard versions of English. Revealingly, although commentators have long lamented the loss of local English cultural variety in the wake of a centralizing national standard, they have not found it necessary to frame this complaint in colonial terms. Indeed, one of the weaknesses of Scottish postcolonialism is that its concentration upon the construction of Scottish lin- guistic inferiority leaves critics blind to the social exclusion of the English working class. This is perhaps most obvious in a tendency to conflate English (as a language variety) with Standard English, a tendency that perhaps originates in Hugh MacDiarmid's seminal essay "English Ascendancy in British literature." 19 This serves to enhance the self-Othering tendencies of the colonial narrative in Scottish studies by designating Standard English a foreign tongue in Scotland, rather than an official variety of local speech as in England. This conflation may also serve to emphasize the distinctiveness of Scotland and England as internally coherent and mutually exclusive ethnic groups by distinguishing cultural standardization within Scotland from a general process of cultural standardization consequent upon the modernization of the United Kingdom as a whole. By obscuring a similar history of cultural incorporation within England itself, the suggestion that this process constitutes the English colonization of Scotland performs a nationalist function by transforming the modernization of Scotland from an endogenous process of development into an exogenous form of oppression.

As has been shown already, regardless of the concentration on culture, this analysis depends upon the assertion of English colonization of Scotland in material terms. However, these accounts are rarely accompanied by any detailed analysis of the material consequences of this supposed colonization. This may be because, in contrast to their effect upon cultural life in Scotland, the processes of modernizing the Scottish economy had highly varied disruptive consequences for Scottish social formations and were, for the most part, limited when compared with the impact of similar events in more readily identifiable colonial contexts. Indeed, a proper review of the material conditions of Scottish history makes a colonial definition somewhat difficult. While it has proven hard to define, one of colonization's constant features has been the transfer of indigenous control over social organization to the colonial power. In the case of Scotland almost the reverse is true. Following the Union of 1707, and even more so after 1746 when the threat of Catholic revolt had been suppressed, Scotland retained comparatively high levels of autonomy relative to any international comparison, including that with many of the minor "nations" of Europe. ${ }^{20}$ Scots continued to serve at the highest level of government both in Britain's imperial possessions and, in ways crucial to the present argument, within Britain itself. In India, Scots served as governor general from 1785 to 1786,1807 to 1813 , and 1847 to 1856 , as well as a six-month period in 1823. More importantly, in terms of any notion that England colonized Scotland, Scots were continually elected to represent English and Welsh constituencies in the British parliament, including sixty members of parliament between 1760 and $1790 .{ }^{21}$ 
At the time of writing this paper the British prime minister was born and educated in Scotland while in the cabinet Scots hold the posts of chancellor of the exchequer, Northern Ireland secretary, Scottish secretary, secretary of state for transport, lord chancellor, and leader of the House of Commons. ${ }^{22}$ Scotland has also historically produced a large professional class in occupations such as engineering and medicine. So, while Oxford and Cambridge produced only 500 medical doctors between the years 1750 and 1850, Scottish universities produced 10,000, many of whom went to work in England as well as in the British colonies. ${ }^{23}$ In order to claim that Scotland was colonized it is necessary to ignore these material indicators that suggest that, as a whole, Scotland benefited greatly from the processes of modernization following the union with England, and, indeed, that these were processes over which Scots themselves exercised considerable control.

\section{The Provenance of a Colonial Analysis of Scotland}

It is understandable that academics working in literary studies should concentrate on the cultural features of Scottish history rather than the materialist history described above. Yet this concentration makes the use of a term like colonization problematic because of its clearly materialist basis. To understand this contradiction it is helpful to chart the recent provenance and the growing acceptance of a colonial analysis of Scottish history. Furthermore, the effort to account for its growing credibility offers revealing evidence about the political significance of a postcolonial reading of Scotland. There are arguably three main reasons behind the increasing adoption of this political model as a way of explaining Scotland's relationship to the British Union: an increasing divergence between the Scottish economy and the politically powerful economy of southern England combined with a geographical divide in electoral terms; changes in the economy of British universities that have increasingly required researchers to address an international market; and the suitability of a colonial analysis to the nationalist paradigms of Scottish literature coupled with the decline of more traditional, political explanations of a materialist kind.

\section{Changes in the political-economy of Scotland}

The argument that England had colonized Scotland was voiced during the 1920s by an early Scottish nationalist organization, the Scottish National League (SNL). At that time most Scots, including other nationalists, rejected their interpretation of Scottish history, ${ }^{24}$ due in part to a comparison with another "English" colony, Ireland, which many Scots viewed as the site of unpatriotic revolt and the source of deleterious Catholic immigration. Additionally, while the SNL's left-wing language made their claims unpalatable to the Scottish middle class, they also failed to persuade Scottish socialists because they rejected conventional Marxist explanations that "would imply that the Scots had been divided against themselves." 25 Finally, and perhaps most importantly, the SNL view was rejected because it involved a criticism of an Empire that, despite the excesses of the First World War, had not yet been discredited. As this suggests one of the first conditions for a colonial interpretation of Scottish history was the development of a more general embarrassment about Britain's imperial history in the context of decolonization following the Second World War. ${ }^{26}$

After the war, however, the political climate in Britain was principally concerned with social democratic reform leading to a consensus over state-led corporatism, which did much to foster pro-Unionist sentiments among Scots. A major component of this political consensus was the development of a range of Britain-wide gov ernmental and civil structures, which constructed political and social networks between Scotland and England. For example, the development of strong national trade unions, which often negotiated national (i.e. British) conditions of service, saw Scots and English members organized politically for their common benefit. Likewise, the development of a UK-wide welfare state concentrated attention on the benefits of a large-scale public sector made possible by political union. Connections such as these tended to diminish the significance of a separatist politics in Scotland and made a colonial interpretation of the Union less likely. This was to change during the late-1970s and 1980s, however, as this political model came under increasing strain from global economic contraction and an associated policy of reduced public expenditure, instigated under a Labour government by the International Monetary Fund and maintained by subsequent right-wing administrations. In this context, a belief in the failure of an interventionist state led to the implementation of government policies that directly undermined those institutions that had helped to produce Unionist ties in Britain. So, for instance, the Conservative Governments of 1979 to 1997 combined fiscal austerity with a policy of removing the provision of social services from the public to the private sector, thus devolving control and provision of these services from a single, national, organization to numerous locally controlled, private companies. As a corollary, concerted legislation designed to systematically weaken trades unions saw the progressive marginalization of these pow erful Britain-wide organizations from the political process. Not only did such legislation diminish the level of routine institutional contact between Scotland and England, but it was also, in itself, widely unpopular in Scotland, not least because regional economic disparities saw the north of Britain, including Scotland, disproportionately affected by the changing character of the Brit- 
ish economy. Higher levels of unemployment and social deprivation as a product of economic "rationalization" created a greater need for the public services now being cut. Similar disparities in the economies of northern and southern Britain in the early 1990s, saw the government pursue an economic policy intended to cool economic overheating in the south of England at a time when the Scottish economy appeared to be in need of stimulation. In crude terms, this unevenness in the British economy produced a comparable electoral disparity, with the industrial north increasingly voting for the parties of opposition while the Conservative Party was sustained by votes in the south. In the 1987 and 1992 general elections the Conservative Party formed the government due to votes in the south of England, but claimed only ten and eleven seats respectively out of a possible seventy-two Scottish seats. Thus, although it was the leading party in Scotland, the British Labour Party remained the opposition in the British parliament.

These changes resulted in political conditions amenable to a colonial interpretation. Although northern England experienced similar conditions, the historical separateness of Scotland (a distinct kingdom until 1603 and with a separate parliament until 1707) allowed the disparities in the British economy to be interpreted in nationalist terms. For instance, cities in northern England like Liverpool, Manchester, and Newcastle, all with Labour majorities in electoral terms, had similarly suffered from the government's economic policies. How ever, unlike Scotland, they were unable to narrate these tendencies as government by a foreign power. While this remains a minority interpretation in Scotland, the fact that many Scots came to see these conditions as inherent to a British political system is apparent in the widespread support for electoral reform and for a devolved Scottish parliament. It is perhaps also revealing that a Scottish national identity routinely outweighs those who favor independence or vote for nationalist candidates. ${ }^{27}$ This implies that, whatever their voting intentions, Scots are increasingly willing to interpret Scotland's relationships with England in nationalist terms, seeing Scotland as a separate and culturally distinct entity from the rest of the UK. Accordingly, the sociologist David McCrone has identified a rise to prominence of colonial descriptions of Scotland with concerns about the external control of the Scottish economy and a rise in a nationalist interpretation of Anglo-Scottish relations. ${ }^{28}$

\section{Changes in the Economy of British Academia}

McCrone remains skeptical about the empirical basis for such claims ${ }^{29}$ and he has suggested that this tendency "has largely been abandoned by academics." 30 If McCrone is correct about the social sciences, this does not appear to hold true for literary critics who have taken to the colonial model with increasing vigor since the early 1990s. This perhaps suggests something important about the use of the terminology of colonialism in the respective disciplines, with the social sciences demanding a more analytically exact definition of colonization than their colleagues in the liberal arts. What it also seems to indicate is the presence of other motiva tions for the adoption of a colonial methodology in literary studies. Central to these is, arguably, the nature of funding for the humanities within the British university system. While the need to demonstrate the significance of social science research is as great as for the humanities, the apparently empirical basis of their research and the ability to link this work to topical areas of governmental policy provides more tangible evidence for this significance than research in the humanities can claim. One indication of this fact may be the relatively long history of Britain's Economic and Social Research Council when compared to the Arts and Humanities Research Board, which was only recently granted a similar status. For research in the humanities the main arbiter of significance remains publication by established publishers and refereed journals. Significantly, while the Scottish Universities are technically funded by an autonomous Scottish organization, the Scottish Higher Education Funding Council (SHEFC), the formula that this body uses to determine funding remains deeply entwined in UK-wide systems for auditing academic quality. Chief among these is the Research Assessment Exercise (RAE), which judges, among other things, academic publications on their level of "national" (i.e. British) and "international excellence." About seventy-five percent of the SHEFC's funding for research is based upon the scores institutions receive in the RAE. ${ }^{31}$ Within a context where academic monographs and articles in internationally recognized journals are prized most highly, no academic working in the UK can ignore the need to address an international, and especially a North American, audience when seeking publication.

This has created a problem for academics working on Scottish literature. Like "Commonwealth" or "Postcolonial" literature, the main means of including Scottish Literature within the University syllabus continues to be within departments of English literature. There is, for example, only one department of Scottish Literature in the UK, Glasgow University's Department of Scottish Literature, founded in 1972 out of the Department of Scottish History and Literature. The structures of the RAE seem likely to exacerbate this situation because, although the Department of Scottish Literature has become increasingly discrete within the structures of Glasgow University, it is required to submit itself as part of the provision of English Language and Literature in the RAE. Unlike postcolonialism, however, Scottish literature has not been successful in establishing itself as 
a major component in the university study of English literature. Over the last ten to fifteen years most departments of English literature have attempted to offer some provision in postcolonial writing and a significant proportion of academic appointments in British "English" departments advertise a desire for candidates with a specialization in postcolonialism. By contrast, the study of Scottish literature has remained a minority pursuit, even within Scotland. The consequence of this has been to limit the potential for publication of academic material on this subject to a small number of forums. For example, in 1994 the interdisciplinary journal Scotlands was launched by St Andrews University's Scottish Studies Institute, adding to the well established Studies in Scottish Literature, published by the University of South Carolina, and the Scottish Literary Journal, published by the Association for Scottish Literary Studies (ASLS) as serious academic publications with space dedicated for work on Scottish literature. However, by 2000 this new journal had merged with the Scottish Literary Journal to form the Scottish Studies Review, effectively reducing the number of publications dedicated to publishing academic articles on Scottish literature to its pre-1994 level, from which it is possible to infer that the academic interest in Scottish literature does not justify three major journals. In addition, the interdisciplinary focus of this new journal further reduced the annual space dedicated to the publication of Scottish literary scholarship. Over the same period, several journals dedicated to publishing material on postcolonialism have been successfully launched, such as the online journal Jouvert and Interventions published by Taylor \& Francis.

Further indication of the relative interest in postcolonial and Scottish literary studies is provided by the attention that they have received in panels at recent MLA conventions. At the 1997 convention in Toronto, only one panel explicitly addressed a Scottish author: Session 294, "Alasdair Gray: Word, Image, Nation."32 By contrast, twelve panels contained "postcolonialism" in their title, which is to say nothing of sessions that were concerned with issues of colonialism or anticolonial theory, such as the Session 296, "Frantz Fanon and/as Cultural Studies," or Session 632, “Benevolent' (Pre)Colonialism." 33 To survey the MLA sessions for 1997 is to gain a sense of the prominence of issues concerning colonialism, anti-colonialism, postcolonialism, globalization, nationalism, and identity: it is not to gain the sense that there is a great deal of interest in Scottish literature, irrespective of its relevance to many of these issues. This is compounded by a sense that, in the US at least, there is a general misunderstanding of the particularity of Scottish literature; the session on Gray is listed thematically under the "general" subcategory of "Other Literature in English" rather than as "Twentieth-Century British Literature." 34 If not English literature, Scottish writers must form part of British literature if the term is to signify anything at all. If the separation of Scottish writers from Britishness at the MLA convention indicates a recognition of their difference from the mainstream of British literature in ways that critics of Scottish literature have claimed, it does not indicate a clear understanding of Scottish literature's particularity. Moreover, the minor status of Scottish literature within the MLA convention is further illustrated by the fact that the convention included seven panels in the "Irish" subcategory of "Other Literature in English." 35 This suggests both a comparably widespread interest in Irish writing and a corresponding attentiveness to its distinctive qualities.

The MLA convention remains an instructive indicator about the extent of interest in Scottish literature as an area of study, and because of the increasing internationalization of academic study within Britain, it plainly forms part of the disciplinary context for any such work. It is therefore revealing that since 2000 critics of Scottish literature, in attempting to raise the profile of the subject, have organized within the MLA a separate Scottish literature discussion group, which has made that organization more attentive to the distinctiveness of "Scottish literature" as a strand of "Other Literature in English." 36 However, an examination of the extent to which Scottish writing was represented at the 2001 convention indicates that Scottish literature still remains far behind postcolonialism in terms of a wider academic interest. The convention program does list two panels under the Scottish literary subcategory: "The Meaning(s) of History in the Scottish Enlightenment" and "Languages and Enlightenment." 37 Nevertheless, compared to the still abundant papers and panels addressing issues of postcolonialism, colonialism, empire, globalization, and nationalism, Scottish literature remains marginal to the convention program.

The disparity in the fortunes of these two areas of study suggests a motive behind the use of postcolonial theory in relation to Scotland. It seems plausible that aligning Scottish literature with postcolonialism has been part of a strategic attempt to borrow postcolonialism's fashionability in order to provide a wider audience for Scottish literary criticism. To support such an assertion it is noteworthy that attempts to utilize postcolonialism in relation to Scottish literature are often prefaced by claims about the value of this connection: either insisting that it opens up fresh insights for postcolonial studies in general ${ }^{38}$ or castigating postcolonial theorists for consigning the study of Scotland to an "academic ghetto" by ignoring its "less immediately visible cultural differences" in favor of "groups most obviously typified as "other." 39 Such claims are not entirely without merit because questions of identity and nationalism have been central to Scottish culture for the 
better part of a century. It has, therefore, been possible to claim that the development of Scottish postcolonialism is intended to broaden these debates by situating them in an international context. Precisely this argument was made by Douglas Mack whose praise for his own course in "Scottish and Postcolonial Studies" was framed by the desire to open up comparisons between Scottish texts and literature outside the national tradition. ${ }^{40}$ Yet, the associations that his article goes on to make raise serious questions about their descriptive value and suggest that his main intent is to encourage the study of Scottish literature in a wider range of academic contexts. Mack's article appeared in ScotLit, the pamphlet of the ASLS the explicit purpose of which is "to promote the study, teaching and writing of Scottish literature, and to further the study of the languages of Scotland." 41 Mack's article contributes something toward these aims by seeking to entwine the study of Scottish literature with the study of English literature's growth area. Indeed, Mack explicitly links the "development of Scottish literature as a separate discipline" to "recent developments in the teaching of 'English' as a university subject... which have involved a questioning of the old Imperial assumptions that lay behind the traditional canon." As proof of this claim, Mack seems to suggest that the textual features of postcolonialism were already apparent in Scottish literature by offering comparisons between James Hogg's 1824 Confessions of a Justified Sinner and Salman Rushdie's 1988 Satanic Verses, or between Hogg and Chinua Achebe. What is most striking about these comparisons, despite Mack's enthusiasm, is their radical dehistoricizing of the textual features that purport to characterize postcolonialism coupled with an insistence upon a correspondence between the social formations of nineteenth-century Scotland and twentieth-century Nigeria or India. What is perhaps the most significant feature of such comparisons is the professional advantage they offer to Mack who has devoted a considerable proportion of his career in the study of Hogg and is the editor of many recent editions of his work. ${ }^{42}$

\section{The Paradigms of Marginality in a Scottish Context}

If the congruence between professional interests and academic inquiry are especially apparent in Mack's desire to conjoin postcolonialism and Scottish literature, the general use of postcolonialism in Scottish literary studies may constitute a similar response to the institutional marginalization of Scottish literature relative to the proliferation of postcolonial theory. This may be something that is equally apparent in all the increasingly diverse uses of postcolonial theory: among the panels at the 2001 MLA convention, for instance, was a panel on "Postcolonial Chaucer." 43 Nor is this suggestion especially new, being at least reminiscent of Anne McClin- tock's suspicion about the "academic marketability" of postcolonialism. ${ }^{44}$ The point here, however, is not to simply reiterate the frequent accusation that postcolonialism is becoming an "industry." Such claims clearly idealize the immunity of other academic writing to the market, and it seems more accurate to suggest that all academic study is susceptible to this type of strategic adoption of critically fashionable modes of inquiry in order to position itself closer to the center of academic discussion. Nevertheless, it does seem necessary to ask what consequences arise from a particular framing of any critical investigation and, in particular, what political consequences arise from the use of postcolonial criticism in general, with especial attention to the material contexts in which such criticism is and can be written. It is precisely these questions that motivate the present essay.

What is interesting about the institutional marginalization of Scottish literature is the frequency with which it is read as the product of Scotland's social marginalization. Given the degree to which postcolonialism's political analysis seems to depend upon the concept of marginality, this slippage may be a reason behind the adoption of a colonial analysis of Scotland in and of itself. As already suggested, much of postcolonial theory presupposes geopolitical inequalities even if its concern is ostensibly textual. The assumption of an article like Mack's is clearly that the marginalization of Scottish literature within the formal educational contexts is equivalent to those sorts of global inequalities. It is also a major thesis of Robert Crawford's much celebrated Devolving English Literature. Indeed, the idea that Scottish literature developed at a tangent to the English canon as a result of the peripheral status of Scots in an Englishdominated British Union is a mainstay of much modern criticism on Scottish literature let alone attempts to link it to postcolonialism. It is worth restating that this view of Scotland does not mesh easily with the material facts of British history. If the social marginalization of Scotland remains contested, it is worth noting that the development of Scottish literature can be seen to have produced its own marginalization in an academic context.

To understand this point it is necessary to identify with more specificity how Scottish literature can be understood as marginal to English studies at an institutional level. This claim is made problematic by the obvious fact that many Scottish authors appear to be highly canonical. Again the MLA convention provides useful evidence of this. While, in 2001, the discussion of Scottish literature as an identified area of study was limited to only the two panels sponsored by the Scottish Literature Discussion Group, discussion of Scottish authors took place in other papers and panels without reference to their nationality. A three paper panel on 
"Historical Discourses: The Case of Scott" makes no reference to Scott's nationality, while a paper on Robert Louis Stevenson is included in a panel on "Victorians Abroad" (a topic which emphasizes his Britishness rather than his Scottishness). The inclusion of papers on Scottish authors as part of the general study of English literature indicates a certain canonical status for these authors. A more persuasive example might be their routine inclusion in anthologies of English literature. For instance, Arthur Quiller-Couch's Oxford Book of English Verse, which is clearly a central text for the construction of an English canon, included a fairly broad range of Scottish authors. ${ }^{45}$ Likewise, Philip Larkin's Oxford Book of Twentieth-Century English Verse includes a number of Scottish authors. ${ }^{46}$ What is clear from this is that a distinction needs to be made between Scottish authors, who are often highly canonical, and Scottish literature as a whole, which can appear marginal in terms of the structural attention it receives within educational institutions. While it is not the case that Scottish authors remain outside the canon, the degree to which these texts are identified as part of a definable Scottish tradition is extremely limited.

In a claim such as Mack's assertion that the development of Scottish literature was anti- (post) canonical these two concepts are elided, suggesting that the marginality of Scottish literature is equivalent to the marginalization of Scottish authors. Importantly, this can be seen as a necessary feature for the construction of Scottish literature as a curricular area. In order to reconcile the canonical status of individual Scottish authors and a view of Scottish literature as English literature's marginalized Other, this canonicity has had to be transformed into an act of incorporation tantamount to cultural colonization (even where that term is not used). Writers like Sir Walter Scott, Robert Louis Stevenson, or even James Hogg, therefore, become marginal by being positioned as a representative of Scottish literature in toto. In this way, their absolute centrality to English literature obscures their connections to the writing of a separate Scottish tradition, connections that only the independent study of "Scottish literature" can reveal. The development of Scottish literature as a separate discipline, then, partly produced its marginality to the main body of an English tradition by reconfiguring how canonicity should be understood. Significantly, this assertion involved a reconception of the very nature of centeredness within English literature as a subject.

From its inception, the formal study of English literature has maintained an uneasy balance between a cosmopolitan linguistic definition (as literature in English) and a particularistic nationalist definition (as literature of the English). Notably, Scots have historically played an important part in developing the cosmopolitan conception of the discipline by adapting a Scottish rhetorical tradition, grounded on the study of classical texts, to the study of vernacular writing. Recent critical accounts of these developments have read them as the "Scottish invention of English literature." 47 Despite this contribution, however, the development of Scottish literature as a conceptually discrete area of study effectively reconfigured English literature as a narrow, nationally based tradition, which had incorporated writing from its "peripheries" at the cost of "any role" for that work "within the culture from which its creator derived." 48 The formation of Scottish literature as an object of study saw the articulation, both explicit and implicit, of a nationalist rationale that claimed ownership over the writing of Scots and demanded a conceptual repatriation of that writing from English literature. In doing so it fixed nationality above aesthetic character as the primary organizational concept for tradition and denied English literature the linguistic definition that had permitted the cosmopolitan inclusion of international writing, effectively demanding that English literature became a nationalist phrase in Scottish literature's own image.

Undoubtedly, this narrower definition of English literature had always been in place, and the proliferation of postcolonialism within literary study has been facilitated by, and responsive to, the nationalist function that the study of literature has played. There are several wellknown accounts of the role that the study of English literature played in the maintenance of colonial governance. ${ }^{49}$ Nevertheless, the arguments for the independent study of Scottish literature forcefully reify this conception by recasting English literature's cosmopolitanism as an aggressive assertion of the cultural domination of marginal social groups by an Anglocentric elite. Moreover, despite the insistence that the teaching of English literature in Scotland represented a form of "internal colonialism" or English "cultural imperialism," there is an unresolved paradox in Scots' continuing identification of Scottish education as one of those "national institutions" that gives Scotland "a distinctive inflection that is more than regional." ${ }^{50}$ Scottish education is asked to stand both as the marker of Scottish nationality and the site of England's domination of Scotland.

The roots of this contradiction are, arguably, imbedded in precisely the sort of institutional and economic imperatives that have contributed to the emergence of Scottish postcolonialism. While Scottish literature unquestionably requires a fully conceived geopolitical notion of Scottishness for its realization, ${ }^{51}$ the institutionalization of that category has also been the product of the active lobbying of Scots along fairly traditional nationalist lines. From its inception, the formal study of Scottish literature as a discrete disciplinary specialization has been accompanied by the explicit claim that such study was necessary to preserve the national—and often 
"racial" - particularity of Scotland. ${ }^{52}$ What is also clear is that such arguments often served as an attempt to insulate autonomous Scottish educational institutions from further competition with their English counterparts by developing explicitly Scottish curricular areas of study. 53 To that end, the strategic adoption of postcolonial theory within Scottish literature as a form of selfpromotion fits neatly into a history of institutional advancement that involved the development of minority areas of study.

More saliently, the nationalist structure of Scottish literature as a subject area has been instrumental in reading the institutional marginalization of Scottish literature as the marginalization of Scotland in social terms. This relates directly to the use of colonization to describe the political settlement between Scotland and England. To that end, one explanation for the relatively recent development of a colonial reading of Scotland is the relative novelty of Scottish literature as an area of study, the widespread interest in this subject area dating from the late 1960s at the earliest. It needs to be reiterated, however, that the use of colonization in relation to Scotland is deeply antimaterialist and unhistorical in the liberal sense. Appropriately, few of the accounts of Scotland's social marginalization employ much material evidence of this process. This apparent antimaterialism seems to be a consequence of the nationalist paradigm for Scottish literature. Because a nationalist interpretation insists that Scotland is epistemologically as well as structurally discrete from England, the development of a Britain-wide cultural standard is interpreted as evidence of the diminution of Scottish particularity, which has been read as Anglicization. The turn to postcolonialism seems to have aided this analysis, in providing a language in which this Anglicization can be understood in systematic ways-as colonization. This has been encouraged in turn by the increasing attention to culture in postcolonial analysis and to a consequent imprecision in the use of postcolonialism key terms, terms that originated in a political rather than a cultural critique. This shift is characterized in the degree of interchangeability of imperialism and colonialism as terms, whereby the organized process of colonization, encapsulating the varied processes of occupation and economic exploitation, subsumes the systematic internationalization of capital by which Lenin defined imperialism. ${ }^{54}$

Arguably, the elision of these two terms in postcolonial studies and the development of a colonial narrative for Scotland share a common cause, which could be summed up as the retreat from materialist, in particular Marxist, explanatory paradigms within academic study. There are obvious and good reasons for this. The collapse of the Soviet bloc at the end of the Cold War, widely interpreted as the defeat of Marxism more generally, appeared to invalidate many of its diagnoses.
Likewise, Marxism's privileging of class was challenged by the increasingly significant political interventions of the women's movement and racial groups who pointed to the neglect of race and gender as determinants of social inequality. In terms of imperialism, the economism of Lenin's definition undoubtedly underestimated the degree to which imperialism was a form of government and a form of culture with nationalist and racist justifications, as well as being overly schematic about the stages of capitalist development. Yet, the rejection of his definition does not appear to have suggested a consistent alternative, and this has led to a frequent blurring of the distinction between imperialism and colonization. Fatally, this conflation obscures capitalism's continuing monopoly of production at an international level, deflects attention away from its role in producing the cultural consequences that the term "postcolonialism" was conceived to critique, and tends to identify the end of imperialism with the process of decolonization thereby posing bourgeois nationalism as the most likely source of liberation.

The equation of a supposed cultural marginalization with an assumed social marginalization is characteristic of the failure to distinguish imperialism from colonization as processes, which resides in a comparable confusion of two different meanings of the concept of development in relation to both colonization and imperialism in the Marxist sense. While development possessed a cultural meaning within European colonization, whereby European culture was posed as the developed alternative to non-European savagery, it also functioned, and continues to function, as an index of productivity within capitalist economics. In these economic terms development is more than solely a colonial abstraction, and many anti-imperialist theories have sought to explain how development continued to serve an imperialist purpose after colonization. ${ }^{5}$. However, as the equation of cultural and structural transformations in postcolonial readings of Scottish literature exemplify, these two senses of development are often collapsed into one.

It seems likely that the justifications for colonization, which described a civilizing mission in terms of cultural development, were the forerunners to the justifications of international capital, which transformed this mission into economic terms: the Oxford English Dictionary dates the sense of development as a synonym for evolution to the 1840s, whereas its use in relation to the economic development of a "region or people" belongs to the twentieth century. ${ }^{56}$ Nevertheless, the continuing legitimacy of an economic meaning for "development" indicates that these two senses of the word are not commensurate with one another, since an economic conception of the term no longer appears to need an explicitly racial rationale for its justification. The value in 
treating colonization and imperialism as analytically discrete is that it brings more clearly into focus the sort of connections between Scotland and colonial territories that Scottish critics have tried to identify. The connection here is imperialist rather than colonial, characterized by the processes of modernization. The concept of modernization is helpful here because it proposes an interpretative structure, which understands social differentiation as the product of systemic patterns of economic activity. As such it becomes possible to explain the processes of standardization in Scotland without the need to interpret this as the product of social marginalization so often phrased as colonization. For example if we define imperialism economically, we are able to explain the similarities between colonization and the expansion of native bourgeois cultures within the borders of European nation-states as characteristics of the general pattern of capitalist development. The apparent similarities between the imposition of British culture within the British colonies and the development of linguistic standards within Britain (in England as well as in Scotland, Ireland, and Wales) can be understood as the need to facilitate the development of capital without recourse to a questionable framework of marginality. It also allows us to identify continuities between nineteenth-century empire building and the, so-called neoimperialism of the late twentieth and early twenty-first centuries.

\section{The Place of Postcolonialism in Scottish Literary Studies}

The developments in the study of Scottish literature that have been described here suggest a number of things. To the degree that the economics of academic writing have become internationalized, the conjunction of Scottish and postcolonial studies indicates a globalization of literary study in general. This may, indeed, be true of the general interest in postcolonialism in whatever context it is found. Concern with this tendency undoubtedly has textual significance, and work such as Graham Huggan's discussion of what sort of textuality can be marketed as marginal is helpful in charting the nature of these developments. ${ }^{57}$ However, the globalization of literary study also requires attention to the political and economic contours of access, distribution, and inequality. While the presence of the market in academic institutions within Britain may appear to have become more conspicuous than it was during much of the twentieth century, the economics of education still construct significant inequalities between the G11 economies and the rest of the world. For all the marginalization of Scottish literature as an area of study, Scots clearly sit on the privileged side of such a division.

If postcolonialism, as an area of literary study, is to address the sort of political and economic inequalities within which the global perspective of academic writing is implicated, critics needs to ensure that they acknowledge the social and political consequences of its analysis as they refer to ever more diverse scenarios in postcolonial terms. In advancing the sort of political critique that is foundational to postcolonialism, postcolonial analysis needs to retain a genuinely interdisciplinary approach. Because of its strong tendency to ally textual analysis with political diagnosis, postcolonial studies must remain sensitive to the political and economic aspects of these theories as well as their cultural concerns. This requires teachers and scholars to seek, where possible, to expand the curriculum in ways that acknowledges the impact of other disciplines upon our understanding of the meaning and significance of texts: to guard against the tendency to privilege practical criticism over the broader claims of postcolonialism. As an example of what such criticism might involve in relation to Scottish literature, an article by Douglas Gifford, which attributes difficulties in obtaining texts by Scottish authors to the concentration of the publishing industry in London, may be more helpfully postcolonial than more recent attempts to paint Scotland as England's colonized Other. ${ }^{58}$ It seems likely that the historical role of the text in literary studies as a discipline has been influential in limiting the amount of writing that uses Gifford's approach, and has encouraged critics to make the much more frequent claim that Scottish literature is postcolonial. ${ }^{59}$ However, as has been suggested, this formulation also has its roots in the increasing imperative to publish with the centripetal consequences that arise from this. The more that postcolonialism is consolidated as a way of talking about texts, the greater the advantage in linking its methodologies to an ever-expanding range of research interests. Likewise, the enduring nationalization of literary study, and the importance of canonization to this model—both as an assault on a supposedly Anglocentric canon and as an attempt to constitute an alternative Scottish tradition-has encouraged a narrative of marginality within Scottish literature studies. Yet, as if to prove the need for more interdisciplinary modes of inquiry, Scottish claims to institutional marginalization have been unable to resist reading this marginalization in social terms, seemingly without a sufficiently materialist explanation of how this is constituted and where its significance lies. The left wing origins of many of the terms of a materialist analysis - such as the Marxist critique of imperialism - will be unpalatable to many. The challenge to them is to develop alternative explanations of the material consequences of the concepts that they deploy. The insertion of the word "cultural" in front of imperialism or colonization cannot be an excuse for ignoring the political and economic basis of such concepts. Cultural colonization does not exist--indeed, cannot exist-independently of systems of economic 
production. For Scottish literary studies what is urgently required is a materialist explanation of how Scots were able to benefit economically and politically from the structures of the Union and how certain characteristics of Scottish cultural distinctiveness were able to survive in the face of increasingly normative forces of cultural standardization. Such an explanation would include recognition of the fact that certain cultural forms, such as written language, were more susceptible to standardization than others as a result of modernization's need for repeatable skills. Such an explanation would also have to accept that the nationalization of this process is not, or not immediately, the product of modernization so much as a mode of resisting or accommodating modernization. The similar tendencies to cultural standardization in Scotland and in England suggest that, insofar as Scottish nationality was a feature of this process, it arises from Scots' ability to conceive of themselves as a nation rather than England's identification of Scotland as a foreign nationality in need of assimilation. Certainly, Scottish literary criticism has been far too willing to accept the immanence of "Scottish literature" without conceding it constructedness or charting the processes and motivations behind such construction. This is certainly surprising given how frequently the idea of "English literature" is identified as construct within such criticism. Postcolonialism does seem to provide the instruments for such an analysis, but these instruments need to be employed with more sensitivity to their limitations in a Scottish context. The problem then, perhaps, is not the conjunction of Scottish literature and postcolonial theory, but the readiness to apply postcolonialism and, in particular, its key terms divorced from their politically specific origins as an easy shorthand for more complex issues.

\section{NOTES}

${ }^{1}$ This paper is dedicated to the important work of the Birmingham Centre for Contemporary Cultural Studies, which ceased as a result of its untimely closure during the summer of 2002.

${ }^{2}$ Michael Gardiner, "Democracy and Scottish Postcoloniality," Scotlands 3, no. 2 (1996): 24-41; Ellen-Raïssa Jackson and Willy Maley, "Celtic Connections: Colonialism and Culture in Irish-Scottish Modernism," Interventions 4, no. 1 (2002): 68-78; Stuart Murray and Alan Riach, "A Questionnaire," SPAN 41 (1995): 6-9; Berthold Schoene, "A Passage to Scotland: Scottish Literature and the British Postcolonial Condition," Scotlands 2, no. 5 (1995): 105-122; and Berthold SchoeneHarwood, "'Emerging as the Others of Our Selves'-Scottish Multiculturalism and the Challenge of the Body in Postcolonial Representation," Scottish Literary Journal 25, no. 1 (1998): 54-72.

${ }^{3}$ Robert Crawford, Devolving English Literature (Oxford: Oxford University Press, 1992), 3.

${ }^{4}$ Edward W. Said, Orientalism (London: Penguin Books, 1978), 3.
${ }^{5}$ Kevin J. H. Dettmar and Stephen Watt, eds., Marketing Modernisms: Self-promotion, Canonization, Rereading (Ann Arbor: University of Michigan Press, 1996); Lawrence Rainey, Institutions of Modernism: Literary Elites and Public Culture, The Henry McBride series in Modernism and Modernity (New Haven and London: Yale University Press, 1998); and Ian Willison, Warwick Gould, and Warren Chernaik, eds., Modernist Writers and the Marketplace (Basingstoke: Macmillan, 1996).

${ }^{6}$ Graham Huggan, The Postcolonial Exotic: Marketing the Margins (London: Routledge, 2001).

"Ewen MacAskill, "Welcome to England's Last Colony," The Guardian, 30 November 1996, 19; and Jeremy Paxman, "The English," The Observer, 20 July 1997, 18.

${ }^{8}$ Douglas Mack, "Can Anything Good Come Out of Nazareth?," Scotlit 16 (1997): 4-5.

'Jackson and Maley, "Celtic Connections," 69, 76, 77.

${ }^{10}$ Elsewhere, in a similar essay, Maley critiques Marilyn Reizbaum's suggestion that Irish and Scottish writers share literary similarities, but leaves uncommented her suggestion that "they have comparable 'colonial' histories with respect to England." Willy Maley, "'Ireland, Verses, Scotland: Crossing the (English) Language Barrier'," in Across the Margins: Cultural Identity and Change in the Atlantic Archipelago, ed. Glenda Norquay and Gerry Smyth (Manchester: Manchester University Press, 2002), 13-30 (13, 14); and Marilyn Reizbaum, "Canonical Double Cross: Scottish and Irish Women's Writing," in Decolonizing Tradition: New Views of Twentieth-Century 'British' Literary Canon, ed. Karen R. Lawrence (Urbana: University of Illinois Press, 1992), 165-90.

${ }^{11}$ Schoene-Harwood, "Emerging as the Others of Our Selves," 59 .

${ }^{12}$ Tom Nairn, The Break Up of Britain: Crisis and NeoNationalism (London: New Left Books, 1977).

${ }^{13}$ Cairns Craig, Out of History: Narrative Paradigms in Scottish and British Culture, Scottish Dimensions (Edinburgh: Polygon, 1996), 12.

${ }^{14} \mathrm{~A}$ notable exception is Stuart Murray and Alan Riach's "questionnaire" in the journal SPAN, which seeks to open up debate about postcolonialism's suitability in a Scottish context. Murray and Riach, "A Questionnaire."

${ }^{15}$ Crawford, Devolving English Literature, 50-51.

${ }^{16}$ Homi K. Bhabha, The Location of Culture (London: Routledge, 1994).

${ }^{17}$ Cairns Craig, ed., The History of Scottish Literature, vol. 4 (Aberdeen: Aberdeen University Press, 1987); Crawford, Devolving English Literature; Robert Crawford, ed., The Scottish Invention of English Literature (Cambridge: Cambridge University Press, 1998); and Alan MacGillivray, ed., Teaching Scottish Literature: Curriculum and Classroom Applications, Scottish Language and Literature, vol. 3 (Edinburgh: Edinburgh University Press, 1997).

${ }^{18}$ Scots is the name given to the Scottish dialectical AngloSaxon similar to Northumbrian English, which was identified as a separate Scottish language by Gavin Douglas at the beginning of sixteenth century.

${ }^{19}$ Hugh MacDiarmid, "English Ascendancy in British Literature," The Criterion 10 (1931): 593-613.

${ }^{20}$ Lindsay Paterson, The Autonomy of Modern Scotland (Edin- 
burgh: Edinburgh University Press, 1994).

${ }^{21}$ Linda Colley, Britons: Forging the Nation 1707-1837 (New

Haven and London: Yale University Press, 1992), 49.

22The Labour Party, "The Labour Party-Members of the Cabinet," 2002, <http://www.labour.org.uk/membersof cabinet/> (29 May 2002).

${ }^{23}$ Colley, Britons, 123; and Neil Davidson, The Origins of Scottish Nationhood (London: Pluto Press, 2000), 94.

${ }^{24}$ Richard J. Finlay, Independent and Free: Scottish Politics and the Origins of the Scottish National Party 1918-1945 (Edinburgh: John Donald Publishers Ltd, 1994), 35, 40.

${ }^{25}$ Finlay, Independent and Free, 37.

${ }^{26} \mathrm{~A}$ more precise date might be 1956 , with a shift in attitudes following the Suez Crisis and the realization that Britain no longer dictated its own policy on international matters.

${ }^{27}$ Alice Brown et al, The Scottish Electorate (Basingstoke: Macmillan, 1999), 64-70.

${ }^{28}$ David McCrone, Understanding Scotland: the Sociology of a Stateless Nation (London: Routledge, 1992), 35, 49.

${ }^{29}$ McCrone, Understanding Scotland, 55.

${ }^{30}$ Davidson, The Origins of Scottish Nationhood, 106.

${ }^{31}$ SHEFC, "The Scottish Higher Education Funding Council: Funding for Research 2001-2002," 2002, <http:// www.shefc.ac.uk/content/shefc/research/General/HowSHE

FCFundsResearch01-02.html> (10 December 2002).

32PMLA, "Program of the 1997 Convention, Toronto, Canada, 27-30 December," PMLA 112, no. 6 (1997): 1201-1544 (1298).

${ }^{33}$ PMLA, "Program of the 1997 Convention," 1348.

34PMLA, "Program of the 1997 Convention," 1237-8.

35PMLA, "Program of the 1997 Convention," 1239.

36PMLA, "Program of the 2001 Convention, New Orleans, 27-30 December,” PMLA 116, no. 6 (2001): 1518-1888 (1547).

37PMLA, "Program of the 2001 Convention," 1560.

38Jackson and Maley, "Celtic Connections," 68.

${ }^{39}$ Crawford, Devolving English Literature, 3.

${ }^{40}$ Mack, "Can Anything Good Come Out of Nazareth?"

${ }^{41}$ The Association of Scottish Literary Studies, "ASLS: Index," 2002, <http://www2.gla.ac.uk/ScotLit/ASLS/ Frameset.html> (11 July 2002).

42Stirling University, "Staff Index," 2002, < http://www. english.stir.ac.uk/staff/douglas_mack.html> (27 July 2002).

43PMLA, "Program of the 2001 Convention," 1635.

44Anne McClintock, "The Angel of Progress: Pitfalls of the Term Post-Colonialism," in Colonial Discourse and PostColonial Theory: a Reader, ed. Patrick Williams and Laura Chrisman (Hemel Hempstead: Harvester Wheatsheaf, 1993), 299.

${ }^{45}$ These include: the Anonymous Ballads, Sir Robert Ay toun, John Barbour, Robert Burns, Allan Cunningham, John Davidson, William Drummond, William Dunbar, Jean Elliott, James Graham (Marquis of Montrose), Robert Henryson, James Hogg, James I, Andrew Lang, Alexander Montgomerie, Baroness Nairne ('Carolina Oliphant'), Allan Ramsay, Alexander Scott (?1527-?1590), Sir Walter Scott, Robert Louis Stevenson, James Thomson (1700-1748), and James Thomson ("B.V."). Arthur Quiller-Couch, ed., The Oxford book of English verse: 1250-1918, New ed. (London: Book Club Associates,
1968).

${ }^{46}$ These include: John Davidson, Edwin Muir, Hugh Macdiarmid, Robert Garioch, Norman MacCaig, W. S. Graham, Iain Crichton Smith, and Douglas Dunn. Philip Larkin, ed., The Oxford Book of Twentieth-Century English Verse (Oxford: Clarendon Press, 1973).

${ }^{47}$ Crawford, Devolving English Literature, 16-44; Crawford, The Scottish Invention of English Literature. For my reservations about this argument see Liam Connell, "The Scottish Invention of English Literature ed. R. Crawford. 1998," Textual Practice 13, no. 3 (1999): 561-4.

${ }^{48}$ Craig, Out of History, 19.

${ }^{49}$ Harish Trivedi, Colonial Transactions: English Literature and India, new ed. (Manchester: Manchester University Press, 1995); and Gauri Viswanathan, Masks of Conquest: Literary Study and British Rule in India (London: Faber and Faber, 1989).

${ }^{50}$ Crawford, The Scottish Invention of English Literature, 7, 1.

${ }^{51}$ Glenda Norquay and Gerry Smyth, eds., Across the Margins: Cultural Identity and Change in the Atlantic Archipelago (Manchester: Manchester University Press, 2002), 7.

${ }^{52}$ Advisory Council on Education in Scotland, Secondary Education (Edinburgh: HMSO, 1947), 170-183; Glasgow Herald, "Chair of Scottish History: Disposal of Exhibition Surplus: $f_{15,000}$ Presented to Glasgow University," Glasgow Herald, 17 January 1913, 10; and H. J. Hanham, Scottish Nationalism (Cambridge: Harvard University Press, 1969), 185, 126-8. Depressingly, despite its formation after the typical Romantic spread of European nationalism, Scottish nationalism has displayed all the racially-essentialist features of this tradition. Nairn, The Break Up of Britain.

${ }^{53}$ George Elder Davie, The Crisis of the Democratic Intellect: the Problem of Generalism and Specialisation in Twentieth-century Scotland (Edinburgh: Polygon, 1986), 9; and Donald Carswell, "The Scottish Universities and Some Other Considerations," The Modern Scot 6, no. 4 (1931): 54-57 (55-6).

${ }^{54}$ N. [V. I.] Lenin, Imperialism: the Last Stage of Capitalism (London: Communist Party of Great Britain, 1916).

${ }^{55}$ Kwame Nkrumah, Neo-Colonialism: The Last Stage of Imperialism, ed. Chinua Achebe, African Writers Series (London: Heinemann, 1968); and Walter Rodney, How Europe Underdeveloped Africa, rev. ed. (London: Bogle L'Ouverture, 1988).

${ }^{56}$ The Oxford English Dictionary, 2d ed. (Oxford: Oxford University Press, 1989), development 3.b and e.

${ }^{57}$ Huggan, The Postcolonial Exotic.

${ }^{58}$ Douglas Gifford, "In Search of the Scottish Renaissance-The Reprinting of Scottish Fiction," Cencrastus 9 (1982): 26-30.

${ }^{59}$ This is apparent even in Gifford's own writing, see Douglas Gifford and Neil McMillan, "Scottish literature and the Challenge of Theory," in Teaching Scottish Literature: Curriculum and Classroom Applications, ed. Alan MacGillivray, Scottish Language and Literature, vol. 3 (Edinburgh: Edinburgh University Press, 1997), 3-24. 